\title{
Negotiating Virtue and Realpolitik in Islamic Good Governance
}

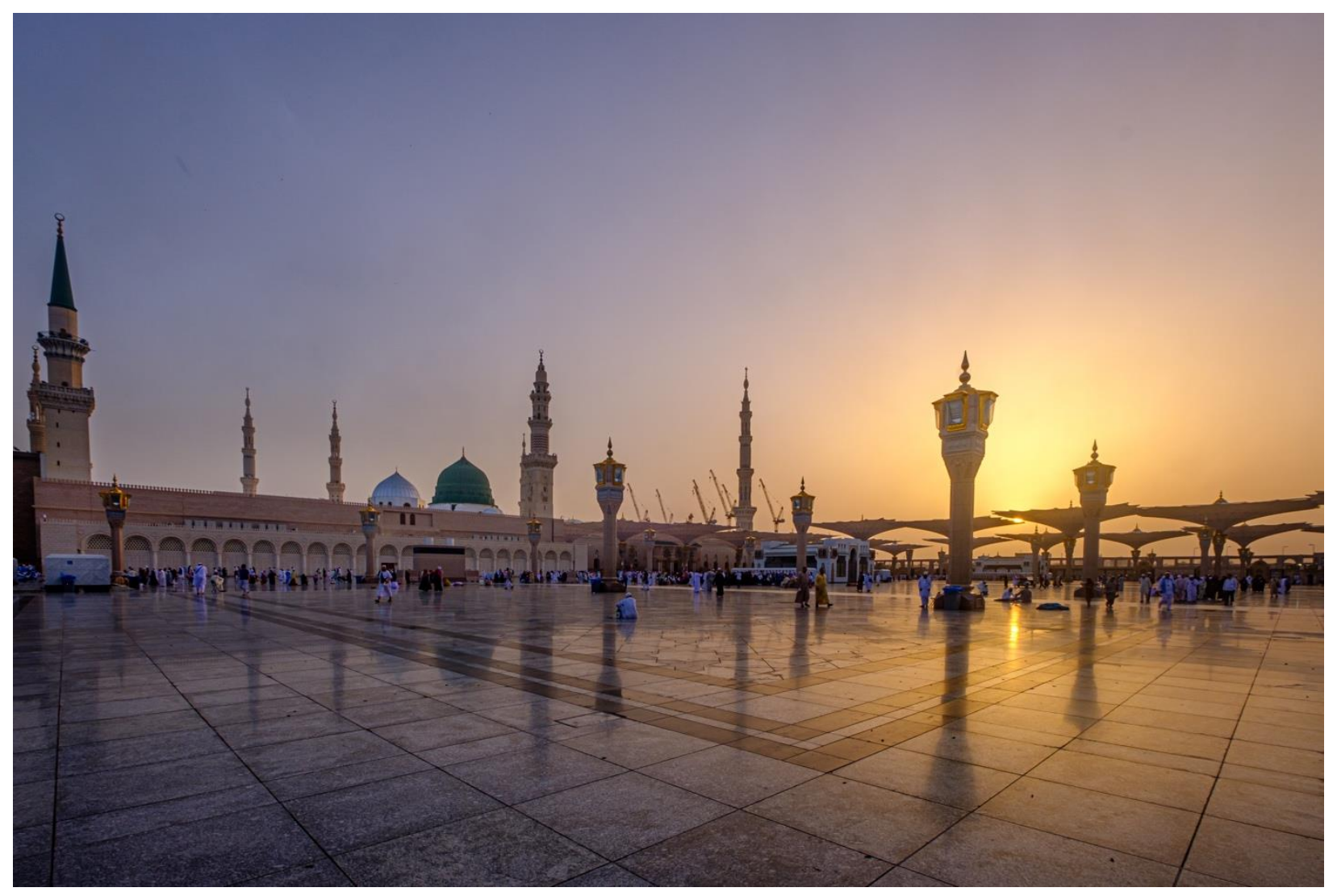

\section{Asma Afsaruddin}

Hamilton Lugar School of Global and International Studies Indiana University, Bloomington

Symposium on Islam and Good Governance

Muqtedar Khan (Ed.)

International Institute of Islamic Thought | October 2020

DOI: $10.47816 / 01.002 .20$ 
"The scars and stains of racism are still deeply embedded in American society... Not one of us can rest, be happy, be at home, be at peace with ourselves, until we end hatred and division." --John Lewis

These words of John Lewis represent a scathing criticism of the contemporary failures of the United States, the oldest and possibly most vibrant democratic nation-state in the world. The words also express a deep disappointment that the principles of equality and justice enshrined in the US constitution have been honored more in the breach when they pertain to African-Americans, many of whose ancestors arrived on these shores long before those of their Euro-American compatriots.

Lewis's sense of betrayal is a potent reminder that words and resolutions in themselves - however lofty and high-minded they may sound do not in themselves create a just and inclusive society. Since the adoption of the US constitution, minority groups African-Americans and Native Americans in particular - have been unable to fully benefit from the rule of law in this country, as both groups have been subjected to systemic discrimination and social denigration as long as the United States has been in existence. Recent occurrences of election gerrymandering and police brutality dramatically confirm that there is indeed a dual system of justice in this country that disproportionately advances the white majority and consistently disenfranchises black Americans in particular.

Muqtedar Khan's thoughtprovoking and remarkable book, Islam and Good Governance: A Political Philosophy of Ihsan, expresses a not dissimilar disenchantment with the course of Islamic political history that he understands to have largely turned its back on the high ideals expressed in the Qur'an and hadith literature about how Muslims should govern their affairs in this worldi. He focuses on the concept of Ihsan, which in the Qur'an is specifically coupled with justice (16:90). Justice in turn is described as an important correlate of taqwa (Qur'an 5:8), a 
fundamental attribute of the believer that the well-known scholar of Islam, Fazlur Rahman, famously rendered as "God-consciousness." This Godconsciousness permeates the notion of Ihsan, as described in the much-cited hadith: "When the angel Gabriel asked the Prophet Muhammad about Ihsan, he replied that it means to worship God as if you see him; if you cannot see him, then surely he sees you." The Qur'an (29:69) promises that God is with those who practice Ihsan, that is to say, with those who carry out beautiful deeds.

Ihsan is a much-invoked and powerful concept particularly within Islamic moral theology and the mystical strain of Islam known as Sufism. Khan provides a useful odyssey through the trajectory of spiritual and mystical Islam in which Ihsan enjoys a particularly high valence, often in self-conscious contrast to the hard-nosed realm of politics, which was guided more by realpolitik and what today we term as "identity politics." It is this development that the author rues, leading him to lament how the adoption of realist precepts by ruling elites have been determined by considerations of political power and practical efficacy rather than the cultivation of moral excellence and virtue. This has led to Muslim political theorists being concerned more with the structure of political administration rather than with the process of political governance.

A more appropriate concern for the latter would lead to the establishment of what Khan calls "the State of Ihsan" that would strive to realize a system of virtuous and benevolent governance in which justice and participatory politics would predominate. In contrast to the state as it evolved in Islamic history, "the State of Ihsan will be concerned with national virtue rather than national identity." More provocatively, Khan states that this State of Ihsan is a secular state. Such a secular state, in our author's conception, is not devoid of religion and religious principles. It is rather a state that "creates an intimidation-free environment that allows various ethical and virtuous communities and even movements to advocate the pursuit of individual and societal perfection."

In the State of Ihsan, the government no longer exercises its authority in a top-down coercive manner but rather interacts and collaborates synergistically with the citizenry to construct a virtuous, 
egalitarian polity. Muslims should be more concerned with Islamic principles of governance rather than with an assumed blueprint for an "Islamic government," which is non-existent in any case, Khan remarks. It is the implementation of these principles that guarantee moral and righteous polities. The hunt for the elusive "Islamic state" of modern-day Islamists is futile and must be abandoned. The conclusion is inescapable: in the absence of adherence to Qur'anic principles, no amount of sloganeering turns a state "Islamic." Islam, after all, is not an empty shibboleth merely to be invoked and publicly professed.

Khan appeals to the example set by the Prophet Muhammad in the seventh century that, he says, must be emulated by contemporary Muslims in establishing their State of Ihsan. The Qur'an (33:21) describes the Prophet as "a beautiful example," signaling the importance of beauty (husn), etymologically related to the term Ihsan, as an attribute that must undergird everything that a Muslim does in emulation of the Prophet. The community and city-state that he established in Medina is a shining beacon for modern Muslims and invites them to similarly uphold the virtues of justice, equality, beauty, mercy, and compassion in the administration of their daily lives and public affairs. Above all, ethics must govern politics in the State of Ihsan.

Khan, however, is not as enamored of the four Rightly-Guided Caliphs who came after the Prophet and says that Muslims must not be so concerned with their legacy as they currently tend to be. He recognizes some of their positive accomplishments but suggests that Muslims go overboard in lionizing them. And here I must express mild dissent with the author. In my own studies of the Rightly-Guided Caliphs, ii I find that the way they are said to have comprehended proper and righteous governance continues to impart important lessons to modern Muslims. One of the fundamental traits associated with the legitimate caliph by seventh-century Muslims is that of fadila or moral excellence. The importance of this concept is enshrined in the general political adage that the most virtuous ( $a f d a l$ ) individual should govern the Muslim community. A quick survey of early Islamic literature reveals that influential Muslim authorities in the formative period remembered the 
early debates about legitimate leadership as having crystallized around the two key concepts of moral excellence and precedence (sabiqa). The best candidates for the office of the caliph drawn from the first generation of Muslims were deemed to have possessed certain virtues, such as charitableness, truthfulness, magnanimity, and courage, while precedence was predicated on early conversion to Islam.

As Sunni sources affirm, Abu Bakr was understood by the majority of Muslims to have met these criteria after the death of the Prophet and, therefore, was considered to be the most qualified to become the caliph. Using very similar arguments, early Shi`i sources assert that Ali, rather than Abu Bakr, was the most virtuous Companion and, therefore, was the best suited to assume the office. Using Khan's terminology, we can say that according to early conceptions of legitimate and righteous governance, Muslim rulers were expected to display and practice Ihsan which, in its capacious sense, includes traits like charitableness and magnanimity considered indispensable in the legitimate caliph. However imperfectly realized in reality, these were ideals drawn from the Qur'an and the sunnah that informed the political consciousness of early Muslims in significant ways. The Rightly-Guided Caliphs also famously practiced shura or consultative governance and considered themselves to be first among equals, eschewing, as our sources inform us, absolutism and tyranny (istibdad). This idealized conception of virtuous, moral leadership is the enduring legacy of the first four caliphs. The principles that informed their administrative decisions are fully replicable today but not the actual mode of government (the historical caliphate) that was a contingent institution applicable for that time and circumstance.

The concepts of precedence and moral excellence, however, progressively receded in socio-political importance with distance from the first and second generations of Muslims. Although moral excellence as a central trait of the most qualified leader continued to be endorsed and upheld as a requirement that must ideally be fulfilled, more pragmatic considerations of effective leadership began to gain ground by the 'Abbasid period. This becomes quite evident in al-Mawardi's writings in the eleventh century and receives greater emphasis in Ibn Taymiyya's works in the 
late thirteenth century during the Mamluk period. Al-Mawardi (d. 1058) maintained that it was no longer necessary that the most virtuous individual assume the caliphate; it was adequate if the candidate possessed the minimum qualifications understood to be necessary for governing the Muslim polity. ${ }^{\text {iii }}$ Ibn Taymiyya (d. 1328) similarly declared that on the issue of good governance, pragmatic and mundane considerations of public benefit and communal welfare should take priority over idealized notions of moral-political leadership. Thus, he stated, one should appoint the individual who is most suitable (alaslah) for a particular position and that their qualifications have to be assessed in view of who would best serve the public interest. Out of consideration for the greater public good (li-maslaha rajiha), Ibn Taymiyya affirms, one may appoint less virtuous but more competent individuals to positions of public prominence, despite the existence of others who are more knowledgeable in religious matters and more pious than them. Thus, for the position of a military commander, the strongest and the most courageous man should be picked, even though "he may have moral failings" (wa-in kana fihi fujur), over the weaker and less capable individual, even though he may be more trustworthy.iv Given the crisis-ridden world that he inhabited - with the memory of the Crusades still very strong and the Mongol invasion underway - it is perfectly understandable why Ibn Taymiyya would emphasize practical, worldly skills over moral probity as the required desiderata in the most qualified leader(s) of his time.

Ibn Taymiyya's influential conception of leadership represents a clear concession to hard-headed realism and a significant modification of the caliphal paradigm of precedence and moral excellence. Aslah ("the most suitable") replaces afdal ("the most excellent") in Ibn Taymiyya's thought. According to him, an individual's greater precedence in some activity is established not on account of any $a$ priori generalized standard of moral excellence but through his "fit" for that particular activity on the basis of pragmatic criteria which maximizes the public benefit to be derived from his appointment. In Ibn Taymiyya's conceptualization, the State of Ihsan was effectively aborted by this 
transmutation and realpolitik was assumed to determine the contours of good governance.

To some readers, the State of Ihsan replacing the modern amoral nation-state may sound preposterously far-fetched and impossibly pie-in-thesky. Can any form of government, after all, remain unsullied by the ambient world in which it functions and refuse to capitulate to realpolitik? As John Lewis's words above remind us, we have, nonetheless, a moral and ethical obligation to try. Otherwise, in the American context, we may never be able to achieve that more perfect union envisioned by the country's forefathers and heal the horrendous racial and ideological divides plaguing contemporary American society. The injustices engendered by the sin of racism can only be transcended by the adoption of values that were meant to animate the American psyche and state formation: equality and justice for all.

Similarly, Khan's extended and eloquent cri de coeur reminds us that Muslims in their own societies must endeavor to aspire towards the Qur'anic ideals of beauty and justice encapsulated by the term Ihsan or surrender to the socio-political cleavages created by the divisive religio-political rhetoric emanating from certain extremist groups today. Though the ideals of beauty and justice embedded in foundational Islamic texts and retrievable from early Islamic society may never be fully or perfectly realized in this world, the very attempt to realize them provides a way out of the spiritual and intellectual morass that afflicts many Muslim-majority societies today. The State of Ihsan will always be a work in progress, ensuring its adaptability and relevance through time. Ihsan's embeddedness in classical Islamic texts and enshrinement in Muslim practices and norms over the centuries are irrefutable, creating a normativity that cannot be disavowed, except through ignorance and rhetorical legerdemain. Khan's invocation of this hallowed tradition specifically in the political sphere is not only timely and necessary but irresistible. 


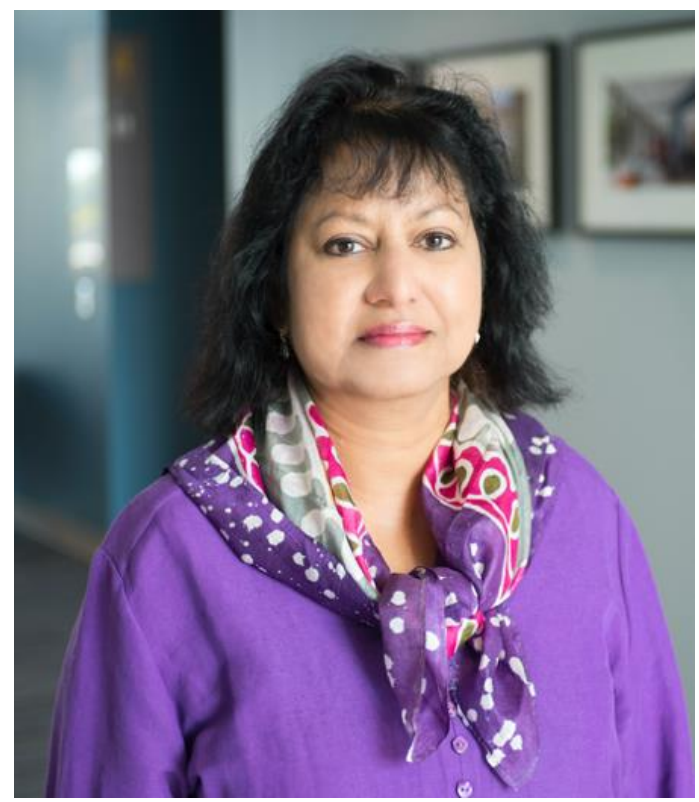

Dr. Asma Afsaruddin is Professor of Middle Eastern Languages and Cultures in the Hamilton Lugar School of Global and International Studies at Indiana University, Bloomington. She is the author and editor of seven books and has written over seventy journal articles and book chapters on topics as diverse as Islamic political thought, Qur'anic hermeneutics, Islamic approaches to war and peace, and gender. In 2015, her book Striving in the Path of God: Jihad and Martyrdom in Islamic Thought (Oxford University Press, 2013) won the World Book Prize from the Iranian Government and was a runner-up for the
British-Kuwaiti Friendship Society Book prize in 2014. She has received research grants from the Harry Frank Guggenheim Foundation, the American Research Institute of Turkey, and the Carnegie Corporation of New York, among others.

Professor Afsaruddin was the Kraemer Middle East Distinguished Scholar-in--Residence at the College of William and Mary in 2012. She is a past member of the Board of Directors of the American Academy of Religion and a current member of the Academic Council of the Prince al-Waleed Center for Muslim-Christian Relations at Georgetown University. She lectures widely in the US, Europe, and the Middle East and has served as an advisor to the Pew Forum on Religion and Public Life, the US State Department, the United States Institute of Peace, and the Woolf Institute at the University of Cambridge. In 2019, Afsaruddin was inducted into the Society of Scholars at Johns Hopkins University in recognition of her academic and professional 
achievements since receiving her

$\mathrm{PhD}$ there in 1993.

i M. A. Muqtedar Khan, Islam and Good Governance: A Political Philosophy of Ihsan (New York: Palgrave Macmillan, 2019).

ii Asma Afsaruddin, Excellence and Precedence: Islamic Discourse on Legitimate Leadership (Leiden: Brill, 2002); idem, The First Muslims: History and Memory (Oxford: Oneworld Publications, 2008).

iii Al-Mawardi, The Ordinances of Government, tr. Wafaa H. Wahba (Reading, UK: Ithaca Press, 1999)

iv Ibn Taymiyya, Al-Siyasa al-shar'iyya fi islah al-ra'i wa 'l-ra'iya (Beirut, n.d.), 23-26. 